\title{
Towards an Understanding of Rich Picture Interpretation
}

\author{
Simon Bell ${ }^{1} \cdot{\text { Tessa } \text { Berg }^{2} \text { (D) } \cdot \text { Steve Morse }}^{3}$
}

Published online: 12 January 2019

(C) The Author(s) 2019

\begin{abstract}
This paper considers the value of the Rich Picture (RP) as a means to capture data from multiple groups exploring a question, problem or issue. RPs emerge from group work by unravelling and integrating understandings, but to date there have been no attempts to consider ways in which the RPs from different groups analysing the same question can be, or indeed should be, objectively compared. The aim of this paper is to investigate the maximum learning potential from the RP, and we develop and use a form of Content Analysis (CA) called Eductive Interpretation (EI) specifically for RPs. The paper illustrates the process of EI by drawing upon a series of RPs created by groups in the Lebanon. The groups were all working on issues involved in coastal zone management, and the resulting analysis presents some of the insights that were gained. The paper finally discusses some of the advantages and disadvantages of EI applied to RPs.
\end{abstract}

Keywords Rich picture $\cdot$ Community OR $\cdot$ Content analysis $\cdot$ Problem structuring

\section{Introduction}

The Systems Science and Operations Research (OR) literature is replete with examples of innovation in data gathering (please see Campbell-Hunt 2008; Langsdale et al. 2009 for two examples) and visualisation - such as that used in diagramming - as powerful means to capture group thinking (Pfeiffer et al. 2008; Salter et al. 2009). However, the interpretation of visual methods remains problematic and this comes into sharp relief when a number of groups are

Tessa Berg

t.berg@hw.ac.uk

1 Faculty of Science, Technology, Engineering \& Mathematics, School of Engineering \& Innovation, The Open University, Walton Hall, Milton Keynes MK7 6AA, UK

2 Department of Computer Science, Earl Mountbatten Building, HeriotWatt University, Riccarton campus, Edinburgh EH4 4AS, UK

3 The Centre for Environment and Sustainability, University of Surrey, Guildford, Surrey GU2 7XH, UK 
exploring the same question. Rich pictures (RPs) were developed as part of Peter Checkland's Soft System Methodology (SSM) as a means to gather information about a complex situation (Checkland 1981). The RP in SSM is a tool used for analysis of a systemic mess or complex situation and provides a space by which participants can negotiate a shared understanding of a context, and part of this, of course, involves them sharing their perspectives and learning from that experience.

RPs have been widely used for many years and applied to a range of projects (Callo and Packham 1997; Haynes 1989; Mingers 2001; Probert 1998; Stamper and Kolkman 1990; Winter and Checkland 2003). They are also used in information systems planning and development (Avison and Fitzgerald 2006). But, beyond the information and systems domains, and detached from SSM, RPs have been put to use in a variety of fora; from nursing (Ballard 2007), social care (Fougner and Habib 2008), the construction industry (Mazijoglou and Scrivener 1998), creativity (Proctor 1995) landscape visualisation (Boedhihartono 2012) and engineering (Sutrisna and Barrett 2007) to name just a few. In all cases, the RP is applied as a robust means to address contexts of complexity and multiple-interpretation of contentious issues.

The RP is generally agreed to work best within the context of a small group ( 2 to 6 people) that encourages creative problem identification through visual understanding of complex socio-technical systems (Bronte-Stewart 1999). Indeed, Bell et al. (2016, p13) note that ' $R P$ 's have had their widest and most successful application in the field of participatory and community work". As commonly practiced and as originally intended in SSM, RPs tend to be the 'front end' of problem structuring methods and they have, to date, been seen as an early enquiry tool in system design and their real usefulness expires after the completion of this phase (Checkland and Poulter 2006). RPs are known to be highly versatile and hence applicable and useful in a wide variety of contexts (for example see: Sutrisna and Barrett 2007; Bell and Morse 2013) but they are difficult to interpret in the sense of third parties being able to 'read' and draw meaning from (see for example: Carrizosa 2002; Bell and Morse 2012) and this is a conundrum which we will explore within the paper. In terms of data capture from a group, the RP has the advantage of having few formal rules and is usually a physical picture drawn by a variety of hands to encourage community discussion and debate. But, how might RPs be interpreted for meaning? This is especially relevant in a comparative sense. For example, in a participatory workshop that might comprise a number of small groups drawn from a community but asked to explore the same question it is highly likely that the analyses they arrive at will also be very different. Some groups may well agree on the importance of a number of key issues, but it is also likely that there will be differences in perspective. We argue that the multiple perspectives contained in RPs produced by a number of groups all exploring the same question provide an opportunity for deeper analysis. This begins with an analysis of similarities and differences but can then go much deeper as we ask questions about why it is that these may exist? Can we regard points of similarity in RP content across groups as reflecting a deeper sense that these are the points that are really core or can they simply be reflecting a given and oft-articulated agenda set by politicians etc.? Apparent differences in RP content may perhaps be a function of factors such as group composition (different skills, jobs, genders, ages, experiences etc.) but they may also reflect differences in group function, but it could also be that these apparent differences are divergent ways of looking at the same underlying issue and thus offer a degree of triangulation. But how can we understand the pictures and interpret, correctly, the visual metaphors? The analysis of RPs across groups has been little discussed in the academic literature to date, probably because the outcomes of a RP 
exercise remain qualitative, subjective and contested. Meaning derived from pictures is disputable and 'truth' is hard to confirm. The culture of those stakeholders involved in the drawing process might be different from the culture of the facilitator or evaluating analyst. Probably for these reasons there has been little attempt to address RP interpretation in terms of actual and inferred meaning of the RP itself. There is a lack of universal standards and a gap in our capacity to generalise from art interpretation methods (Berg 2013).

In what follows we set out an approach which we think will help with an analysis of RPs. Such analysis will benefit both the researcher and group offering insight into concerns, issues, secrets, visual meanings and individual stories. We fully acknowledge and respect the origin and role of the RP within its SSM context, and it should be noted that analysis of RPs is not intended to impinge upon or disrupt the use of RPs within an SSM or indeed any participatory process. Instead we make the case that the Content analysis (CA) of RPs can be undertaken outside of that problem-solving context to provide useful insights into the results of the analysis completed by the individuals/groups. Here we illustrate how the RP can provide the material for a CA to explore common themes and issues as well as differences which emerge between groups (or individuals) asked to analyse the same topic. We argue that the messages, stories and emotions within the RP can be drawn out, or educed, by making use of an approach we call Eductive Interpretation (EI) which is a form of CA that provides a refined, systematic (sequential and methodological) and systemic (inclusive) way of analysing RPs - assisting groups in reflecting on and looking specifically at their RPs in terms of differences. In order to do this, the paper will draw upon a series of RPs produced during a workshop undertaken in the Lebanon on a coastal zone management project. We chose this case study as it represents a complex system for RP to address especially in a challenging country context.

\section{Lebanon Case Study}

Our entry point for the research reported here is taken from a series of interventions in the Lebanon (PlanBleu and Bell S 2002a, b; PlanBleu and Bell S 2003a, b). Lebanon is a country with a complex and difficult past and indeed present.

The history of the Lebanon, a country of just over 4 million people at the time of writing, cannot be divorced from the chronic issues of empire and conquest stretching back before British and French imperialism and taking in the sweep of the Ottomans and more local Arabic and Phonecian influences. Hence the historical context is long and complex and cannot be the subject of this paper. Although the situation in the country is often portrayed as dangerously conflictual, there is also a significant degree of consensus which often remains understated (Azar 2002). Its geographical location on the shore of the Mediterranean provides opportunities for tourism but also raises challenges faced by many of the other countries that also have a coastline on that sea, including intensive development and pollution arising from urbanisation and industrialisation. But the Lebanon also has borders with Israel and Syria, and this has brought other sources of turbulence that echo down to this day. The case we develop is based upon a project which was focused on the Lebanon during a comparatively peaceful period (2002 to 2003). The project was part of a Coastal Area Management Programme (or CAMP) undertaken by the French environmental agency Plan Bleu throughout the Mediterranean. CAMP was oriented at understanding and resolving practical environmental, development and management problems at local and national levels in Mediterranean coastal areas. At the time of the CAMP project in the early 2000s the need for an improved coastal area management 
plan was regarded as being of key importance. This focus on sustainability for the coastal zone was to be facilitated by the use of a method derived in part from SSM, with the first stage involving the creation of RPs by groups. The workshop used for the research reported here took place in 2002 and involved approximately 30 individuals (divided into four groups of 7 to 8 people) drawn from the coastal zone area (resident no more than 2 miles from the coast), and was $75 \%$ male, $25 \%$ female. The individuals were mainly drawn from local professionals, representatives of local government and of non-governmental organisations. The key qualification for all was that they were keenly interested in the health and status of the coastal zone and its development.

Workshops were organised around the greater Beirut area, the RPs included here were all produced at the first workshop. At the workshop participant groups were provided with discrete space and supplies of paper and pens in order to map out the main components of their assessment using visual metaphors. Some time was invested in explaining the RP process and fielding questions about the value and use of pictures and diagrams in describing situations. The groups were given around an hour to draw their pictures and to prepare for a briefing for plenary.

In this paper we will not provide the full results of the workshop and instead will conceptualise the RPs as providing the 'pre-analysis' of coastal zone sustainability. It is the groups 'situation summaries' which the stakeholders used to capture the real situation as they saw it. Figures 1, 2, 3 and 4 are the RPs produced by the four groups who took part in the workshop.

\section{Content Analysis of the Lebanon Rich Pictures}

Once the RP has been developed it can subsequently be assessed for meaning using content analysis via Eductive Interpretation (EI). In our experience the messages, stories and emotions

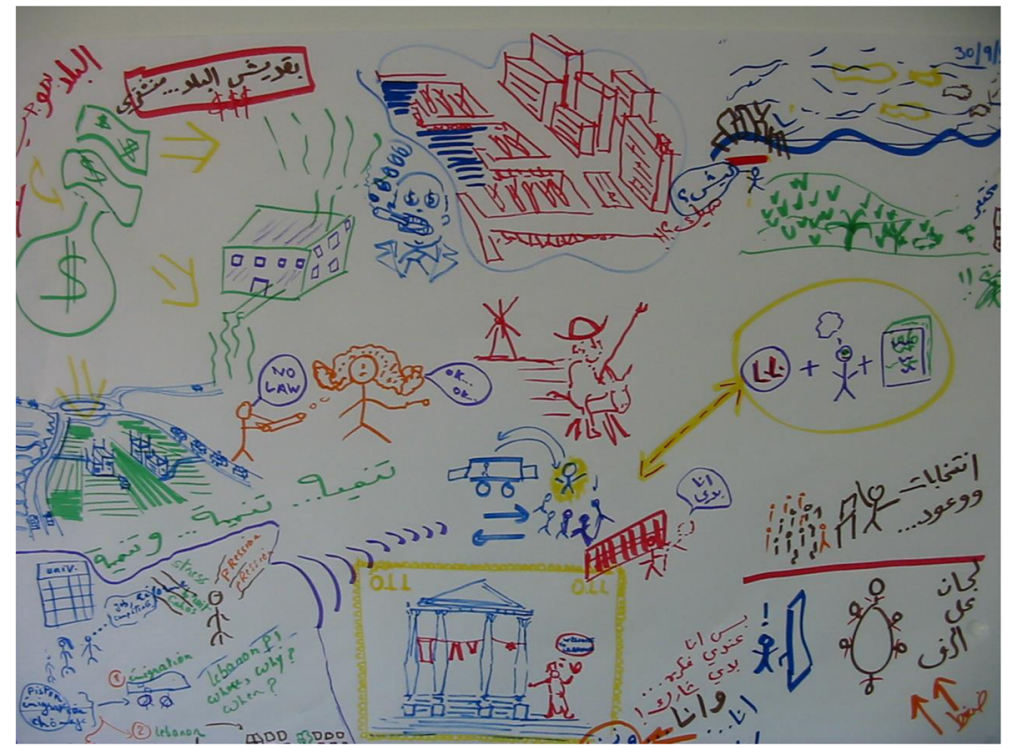

Fig. 1 Lebanese Rich Picture 1 


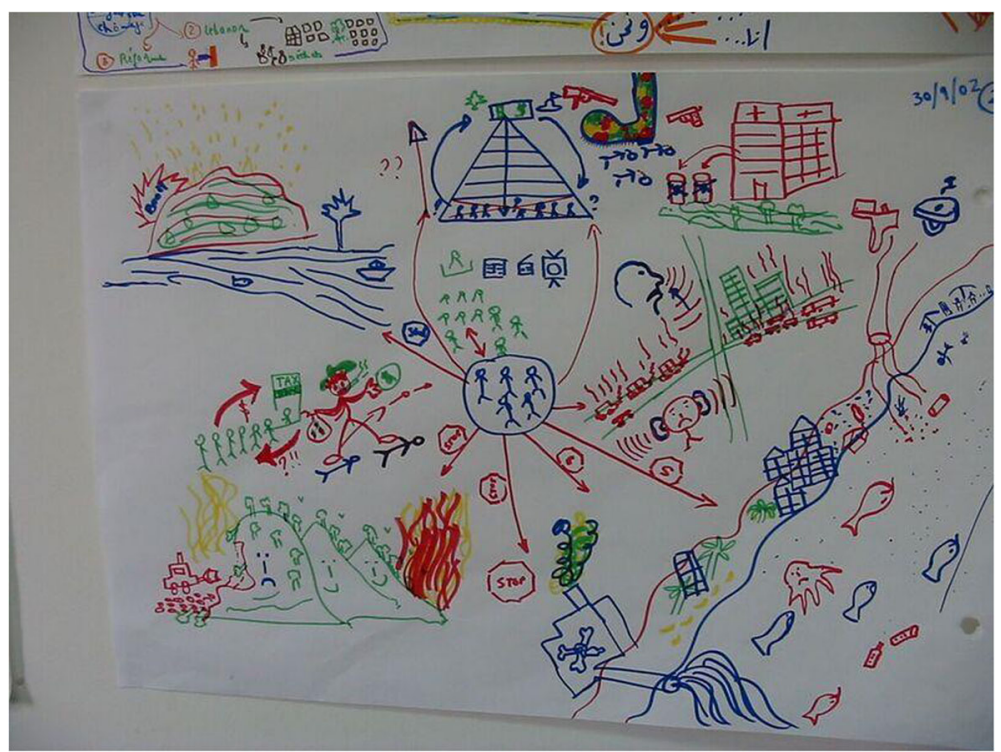

Fig. 2 Lebanese Rich Picture 2

within the RP can be drawn out, or educed, by making use of an approach we call Eductive Interpretation (EI). EI is a form of Content Analysis (CA) that provides a refined, systematic (sequential and methodological) and systemic (inclusive) way of analysing RPs - assisting

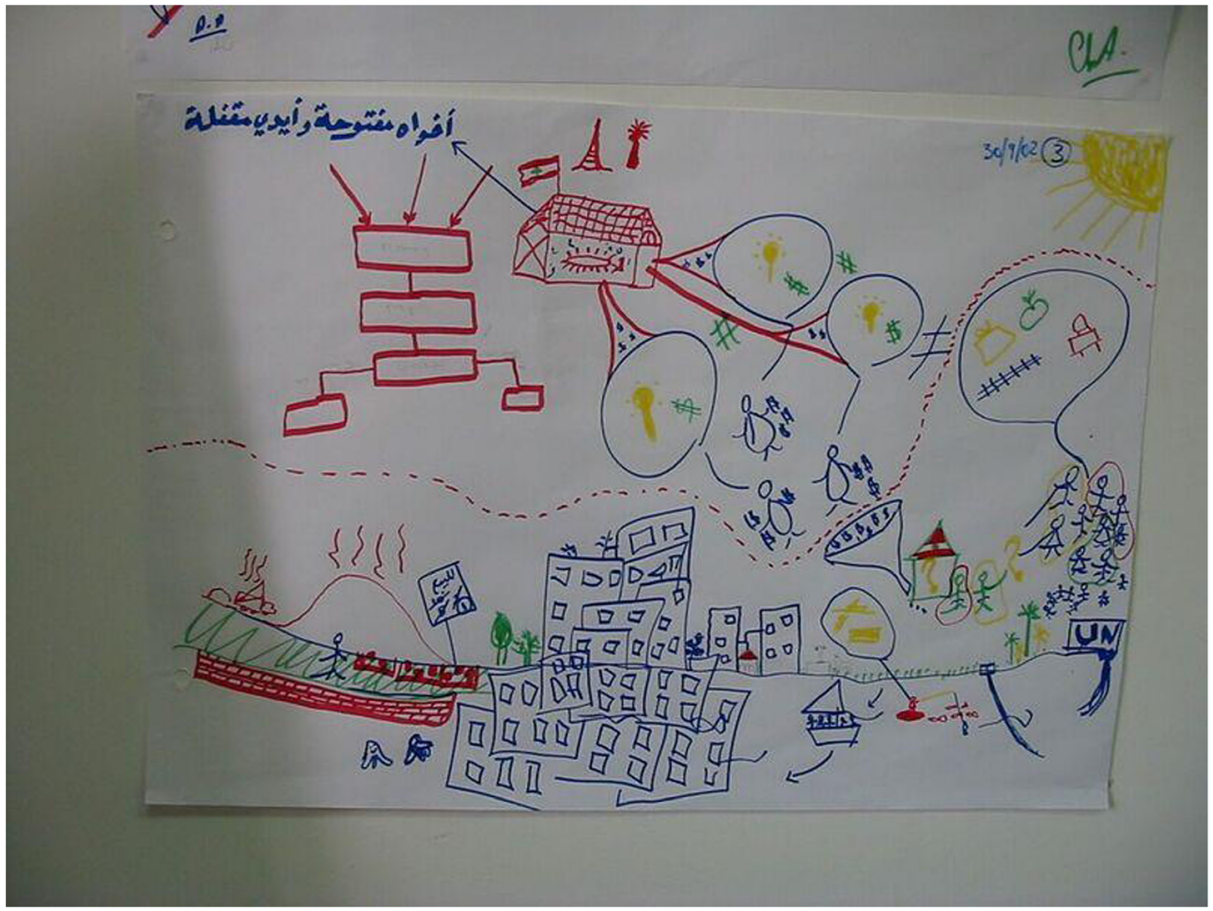

Fig. 3 Lebanese Rich Picture 3 


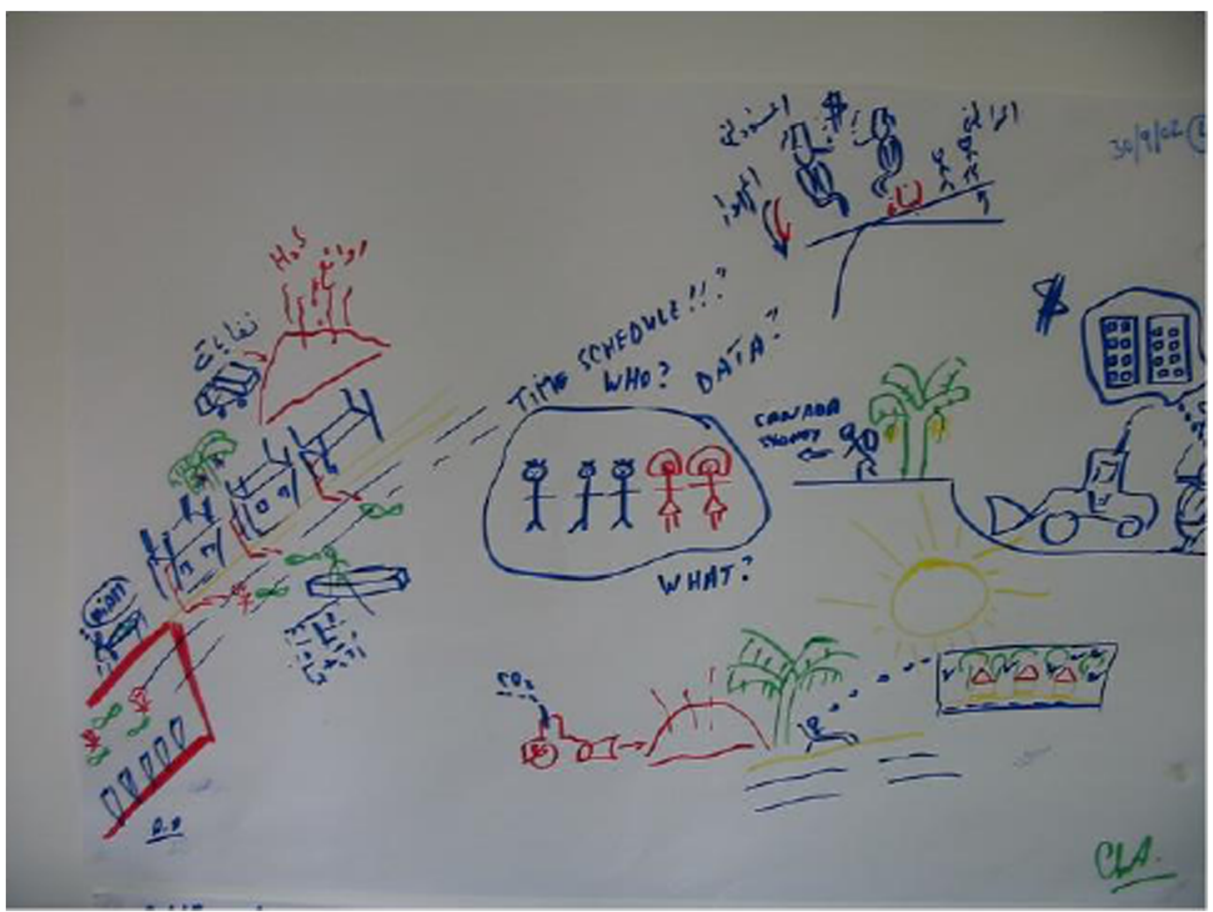

Fig. 4 Lebanese Rich Picture 4

groups in reflecting on and looking specifically at their RPs in terms of differences, similarities and relationships.

CA is a widely recognised qualitative assessment tool primarily used in the social sciences and humanities. CA is used to identify patterns and relationships within a variety of materials such as interview transcripts, video, audio and pictures. In essence, CA looks for patterns and themes that can be clustered to make sense of complex, and often bulky/messy data. EI as suggested here is, in effect, a form of Content Analysis for visualisation. Thus EI, when applied to RPs, provides groups with a "deep-dive" exploration of the many visual metaphors held within a picture.

The aim is not to judge the RPs and we are not trying to apply authority as expert evaluators nor do we assert this evaluation should be part of a process such as SSM. Hence, we are not suggesting that the CA be done by workshop participants or indeed by facilitators during the workshop. In a conventional CA the pictures and related workshop discussions would be scanned for meaningful content which is of comparative interest both in the comparison of various artefacts (in this case RPs) and in terms of the rigours of the context under scrutiny (in this case the coastal area of Lebanon. Tables 1, 2, 3 and 4 provide different 'takes' on the RPs (Figs. 1, 2, 3 and 4) of the Lebanon groups. Each of Tables 1, 2, 3 and 4 contains three discrete elements of information:

- Column 1: This contains the deduced key themes evident across all four RPs. These key themes emerged from a segmental analysis of each RP as shown in Fig. 5. Each RP was divided into nine segments and each segment was analysed individually for content. This resulted in a sequence of educed themes as seen in column 1 of Tables 1, 2, 3 and 4. 
Table 1 Analysis of Rich Picture 1

\begin{tabular}{|c|c|c|}
\hline EI themes & CA RP1 & \multirow{8}{*}{$\begin{array}{l}\text { Stakeholder EI RP1 } \\
\text { We are fighting against time ('chasing windmills' like Don } \\
\text { Quixote) - empty dreams. } \\
\text { There is no development in the fields of agriculture and fishery - } \\
\text { no technological advances. } \\
\text { Elections are about empty promises and local committees are } \\
\text { papers on shelves [Dis]. } \\
\text { Many have dreams and hopes but the door is often closed unless } \\
\text { they use 'wasta', i.e. personal connections with powerful persons or } \\
\text { groups [Dis]. } \\
\text { Brain drain and emigration without return due to high } \\
\text { unemployment rates [Em]. } \\
\text { Some people, like the CAMP team, are hopeful and attempt to } \\
\text { make changes but are shocked with the amount of existing damage } \\
\text { in urban plans. } \\
\text { The team's main role is to be 'the ears of the community' and to } \\
\text { link resources (expertise, information, and funds) to deal with } \\
\text { community challenges. }\end{array}$} \\
\hline Stakeholder style & $\begin{array}{l}23+\text { basic stick figures, } 2 \text { full } \\
\text { figures(B2,B3) }\end{array}$ & \\
\hline $\begin{array}{l}\text { Facial expression/ } \\
\text { body language }\end{array}$ & $\begin{array}{l}\text { One clear face (B1) depicting a } \\
\text { person of power ( cigar and } \\
\text { dress). Body language of man } \\
\text { on Horse ( B2)looking } \\
\text { behind/being reflective }\end{array}$ & \\
\hline $\begin{array}{l}\text { Dominant } \\
\text { stakeholders }\end{array}$ & $\begin{array}{l}6 \text { instances: } \mathrm{B} 2, \mathrm{~B} 1 \\
\mathrm{x} 2, \mathrm{~B} 3, \mathrm{~A} 2, \mathrm{C} 2\end{array}$ & \\
\hline $\begin{array}{l}\text { Stakeholder } \\
\text { interaction } \\
\text { (groups, } \\
\text { communication) }\end{array}$ & $\begin{array}{l}2 \text { large Groups. One depicting } \\
\text { meeting (B3). }\end{array}$ & \\
\hline $\begin{array}{l}\text { Background } \\
\text { Space }\end{array}$ & $\begin{array}{l}\text { Majority of space used up in } \\
\text { picturing process }\end{array}$ & \\
\hline Dominant icons & $\begin{array}{l}\text { B1 ( large buildings), B2 ( } \\
\text { man/horse),B1 (interaction with } \\
\text { the law),B3 (items being hung } \\
\text { out to dry) }\end{array}$ & \\
\hline $\begin{array}{l}\text { Interesting } \\
\text { metaphor }\end{array}$ & $\begin{array}{l}\text { Man unable to access meeting } \\
\text { room (C3),items hung out to } \\
\text { dry (B3), legal issues (A2) }\end{array}$ & \\
\hline Isolation & $\begin{array}{l}\mathrm{C} 2 \text { ( visuals in yel } \\
\text { border not recogn }\end{array}$ & \multirow{7}{*}{$\begin{array}{l}\text { Many people are entrepreneurs but individualistic - it is time to } \\
\text { join forces so that we can speak as 'we' instead of 'I'. } \\
\text { - We talk about development but what is development? } \\
\text { There are not enough laws and those that exist are not } \\
\text { implemented nor developed [Reg]. } \\
\text { Cultural heritage exists but it is used for hanging laundry, putting } \\
\text { them on postcards, and the occasional tour guides - no planning, } \\
\text { rehabilitation nor development. }\end{array}$} \\
\hline Speech & All areas except B2 & \\
\hline $\begin{array}{l}\text { Orientation/readi } \\
\text { ng style }\end{array}$ & $\begin{array}{l}\text { No rotation required. Separate } \\
\text { story lines across many areas. }\end{array}$ & \\
\hline $\begin{array}{l}\text { Specific Icons: } \\
\text { Weather }\end{array}$ & $\mathrm{N} \backslash \mathrm{A}$ & \\
\hline $\begin{array}{l}\text { Specific Icons: } \\
\text { smoking } \\
\text { cigarette/cigar }\end{array}$ & 1 instance (B2) & \\
\hline $\begin{array}{l}\text { Specific Icons: } \\
\text { money }\end{array}$ & 1 inst & \\
\hline $\begin{array}{l}\text { Specific Icons: } \\
\text { psychopathic }\end{array}$ & $\mathrm{N} \backslash \mathrm{A}$ & \\
\hline $\begin{array}{l}\text { Stakeholder } \\
\text { plenary } \\
\text { reflections }\end{array}$ & \multicolumn{2}{|c|}{$\begin{array}{l}\text { This picture is an archive, the "story of the project to date" with the possibility of coming up with new } \\
\text { ideas throughout the CAMP process. There is less emphasis on environmental challenges but what is } \\
\text { positive is the focus on local participation and the importance of teamwork. What is also unique is that } \\
\text { there is a piece of every person in that group in the picture. }\end{array}$} \\
\hline $\begin{array}{l}\text { Unique Signatory } \\
\text { of the RP }\end{array}$ & \multicolumn{2}{|c|}{$\begin{array}{l}\text { The RP depicts a colourful yet disorderly visual story of complex situations. There seems to be } \\
\text { numerous, possibly unrelated, communication issues which dominant stakeholders are } \\
\text { controlling. Problems drawn in visuals appear less negative than those listed in the EI. The } \\
\text { stakeholder EI does provide very strong confirmation of the need for change alongside vast } \\
\text { evidence of inadequate current practices. Sense of disconnection is apparent alongside } \\
\text { emigration issues and potential poor governance. The plenary reflection presents a positive } \\
\text { outlook for the future placing emphasis on communication, teamwork and the importance of } \\
\text { listening to the whole community. }\end{array}$} \\
\hline
\end{tabular}

- Column 2: This contains the evidential assessment of each RP in terms of the EI Themes.

- Column 3: This contains the educed observations of stakeholders in the workshop. Within column 3 there is a secondary element of traditional CA analysis on the stakeholder observations. This is a colour coding analysis of topics that emerge across the RPs. As the reader will see in the far-right hand side column of these tables we have the voices (direct quotations as noted by the facilitator) of those who created the RPs. Here they set out what they believe are the main elements of their creations; the key issues and observations of coastal zone sustainability in the Lebanon at that time. We cannot, of course, say whether these issues are still in existence at the time of writing this paper, but these RPs are the stories represented within the RPs in the words of their creators. We have added a bracketed descriptor after the highlighted quote (e.g. Con, Dis, Em, Reg). The criteria 
Table 2 Analysis of Rich Picture 2

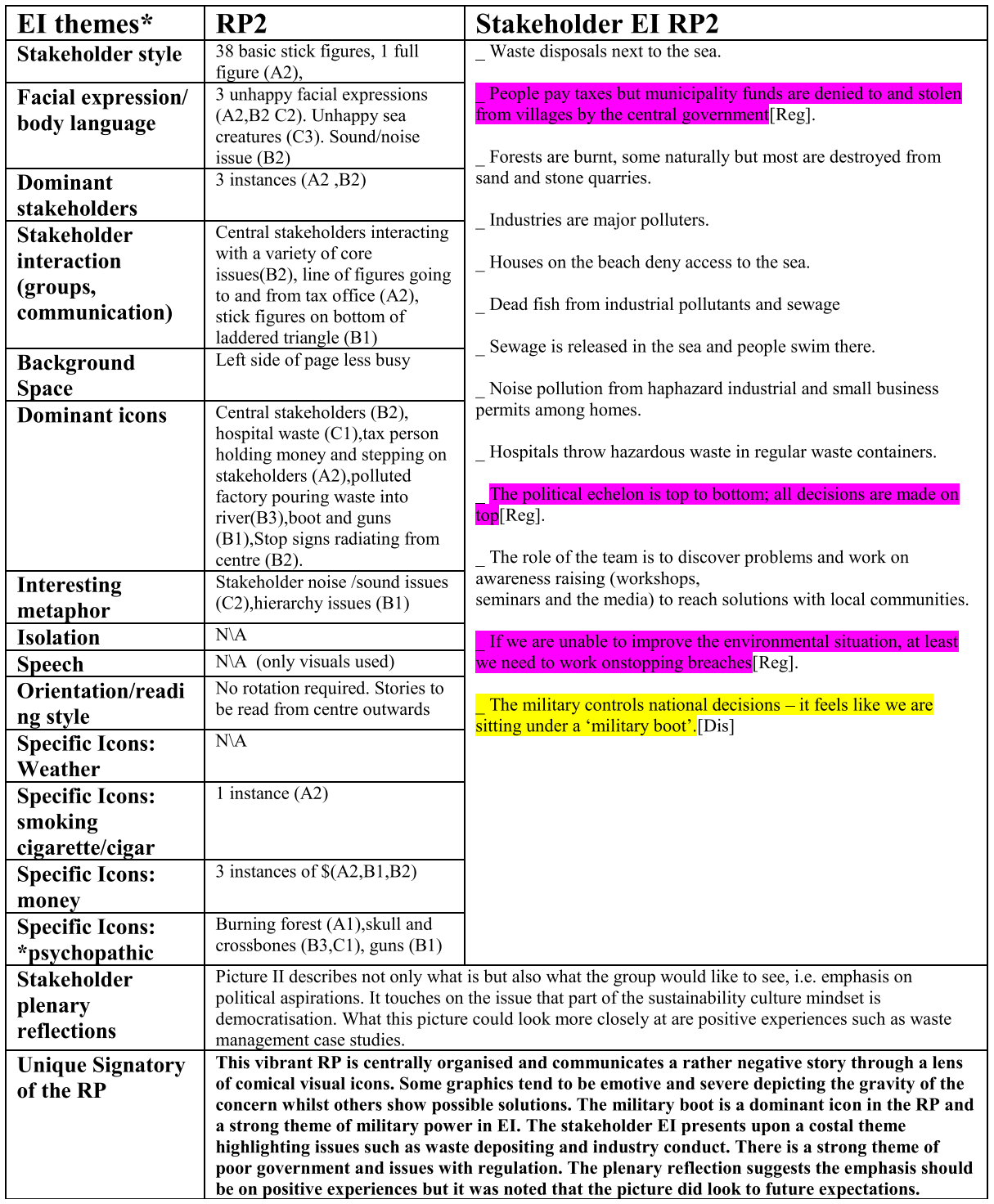

for understanding the secondary CA elements is topic, colour, bracket and topic descriptor: Green: [Con] Control/influence of the military in Lebanon (RPs/groups 2 and 3), Yellow:[Dis] Sense of disconnection in decision making/ lack of power (RPs/groups 1,3 \& 4), Blue: [Em] Emigration (RPs /groups 1\&3), Pink:[Reg] Regulation/poor Government/Enforcement (ll RPs \& groups)

The agreed Plenary reflection which emerged during the workshop is a culmination of the whole RP analysis. This Plenary reflection is on the penultimate row of Tables 1, 2, 3 and 4. 
Table 3 Analysis of Rich Picture 3

\begin{tabular}{|c|c|c|}
\hline EI themes* & RP3 & Stakeholder EI RP3 \\
\hline Stakeholder style & $\begin{array}{l}41 \text { basic stick figures ( some marked as } \\
\text { single lines( eg,B1)), } 3 \text { fuller figures } \\
\text { (B2,C2) }\end{array}$ & \multirow{14}{*}{$\begin{array}{l}\text { Urban growth is eating up rural agricultural } \\
\text { areas. } \\
\text { National policy is controlled by the military and } \\
\text { chaotic capitalism, which only seeks short } \\
\text { term return[Con]. } \\
\text { Impact of the war reflects on the lack of } \\
\text { monitoring[Con]. } \\
\text { Awareness raising activities are useful because } \\
\text { they directly help farmers and fishermen. } \\
\text { _ Emigration without return[Em]. } \\
\text { - Waste continues to grow - no means to reduce } \\
\text { or recycle. } \\
\text { chome people are keen on making positive } \\
\text { changes but politicians do not care[Dis]. } \\
\text { innovative job creation as part of environmental } \\
\text { conservation efforts. }\end{array}$} \\
\hline $\begin{array}{l}\text { Facial expression/ } \\
\text { body language }\end{array}$ & $\begin{array}{l}\text { No facial expressions or body language. } 1 \\
\text { happy sea creature (A3) }\end{array}$ & \\
\hline $\begin{array}{l}\text { Dominant } \\
\text { stakeholders }\end{array}$ & 3 instances $(\mathrm{B} 2, \mathrm{C} 2)$ & \\
\hline $\begin{array}{l}\text { Stakeholder } \\
\text { interaction } \\
\text { (groups, } \\
\text { communication) }\end{array}$ & $\begin{array}{l}\text { Meeting of stakeholders in closed building } \\
\text { (B1), large group with some separated by } \\
\text { boundary ( C2), group on boat going } \\
\text { towards urban area ( C3) }\end{array}$ & \\
\hline $\begin{array}{l}\text { Background } \\
\text { Space }\end{array}$ & Left and top sides of page less busy & \\
\hline Dominant icons & $\begin{array}{l}\text { Issues regarding waste truck and waste on } \\
\text { mountain ( } \mathrm{A} 2) \text {,sprawling urban housing } \\
\text { piled on top of one another(B3), closed } \\
\text { meeting room with picture bubbles } \\
\text { showing light bulb and } \$ \text { signs }(\mathrm{B} 1, \mathrm{~B} 2)\end{array}$ & \\
\hline $\begin{array}{l}\text { Interesting } \\
\text { metaphor }\end{array}$ & $\mathrm{N} \backslash \mathrm{A}:$ Many illegible icons. & \\
\hline Isolation & $\begin{array}{l}\text { Single fisherman(C3), hierarchical model } \\
\text { showing empty boxes (A1) }\end{array}$ & \\
\hline Speech & 2 instances ( $\mathrm{A} 1, \mathrm{~B} 2)$ & \\
\hline $\begin{array}{l}\text { Orientation/readi } \\
\text { ng style }\end{array}$ & $\begin{array}{l}\text { No rotation required. Story seems to be } \\
\text { divided (dashed line in centre of page) into } \\
2 \text { main areas. }\end{array}$ & \\
\hline $\begin{array}{l}\text { Specific Icons: } \\
\text { Weather }\end{array}$ & Sun shining $(\mathrm{C} 1)$ & \\
\hline $\begin{array}{l}\text { Specific Icons: } \\
\text { smoking } \\
\text { cigarette/cigar }\end{array}$ & $\mathrm{N} \backslash \mathrm{A}$ & \\
\hline $\begin{array}{l}\text { Specific Icons: } \\
\text { money }\end{array}$ & 19 instances of $\$(B 2, C 2)$ & \\
\hline $\begin{array}{l}\text { Specific Icons: } \\
\text { *psychopathic }\end{array}$ & $\mathrm{N} \backslash \mathrm{A}$ & \\
\hline $\begin{array}{l}\text { Stakeholder } \\
\text { plenary reflections }\end{array}$ & \multicolumn{2}{|c|}{$\begin{array}{l}\text { The focus in this picture is on emigration linked to lack of job opportunities and the importance } \\
\text { of addressing job creation as part of environmental and development plans. The link described } \\
\text { between funding and environmental policies is interesting but what is missing is the role of } \\
\text { stakeholders and their role in natural resource management. }\end{array}$} \\
\hline $\begin{array}{l}\text { Unique Signatory } \\
\text { of the RP }\end{array}$ & \multicolumn{2}{|c|}{$\begin{array}{l}\text { This picture is very people focussed showing numerous groups in difference situations. } \\
\text { Visuals seem to relate to finance and issues of waste. Many icons are difficult to } \\
\text { understand and thus the stakeholder EI was more informative than the RP. The EI notes } \\
\text { problems with dominant stakeholders; politicians \& in particular the military. Emigration } \\
\text { is also evident along with a sense of disconnection with decision making. The main theme } \\
\text { of the plenary was the importance of work creation to resolve emigration problems. }\end{array}$} \\
\hline
\end{tabular}

The emergent Unique Rich Picture Signature (URPS) appears in the final row of the Tables. The URPS is a holistic statement that takes in all the RP analysis and interpretation in one overview providing a summary that is specific to the whole RP investigation.

It should be noted that while we apportioned the RPs into 9 segments as illustrated in Fig. 5 , it is entirely possible that an analyst might feel it more appropriate to divide their picture into 4 , 6 or even 12 segments. In this case the division into 9 segments was deemed suitable for an indepth examination and ideally not too condensed to make analysis overly complex. Similarly, with the highlighted coloured topics we are providing a working example of how one might use EI. In our Lebanon RPs it was appropriate and relevant to provide four coloured topics of 
Table 4 Analysis of Rich Picture 4

\begin{tabular}{|c|c|c|}
\hline EI themes* & RP4 & Stakeholder EI RP4 \\
\hline Stakeholder style & $\begin{array}{l}12 \text { basic stick figures, } 3 \text { fuller } \\
\text { figures }(\mathrm{C} 1)\end{array}$ & \multirow{14}{*}{$\begin{array}{l}\text { Parts of the beach in Naqoura are blocked by the presence } \\
\text { of UNIFIL soldiers and their garbage - they represent the } \\
\text { whole world but they are not the best example in hygiene. } \\
\text { _ Pollution in Naqoura is not high. } \\
\text { _ Naqoura municipality is victim of the Israeli occupation - } \\
\text { no employment opportunities. } \\
\text { There is a barrier between the municipality and people } \\
\text { but there are some areas of cooperation[Dis] } \\
\text { _ one example is that } 90 \% \text { of local taxes are paid. } \\
\text { Some municipalities have money but do not spend them } \\
\text { in an efficient manner[Reg]. } \\
\text { _People's dreams or aspirations for the future are bleak. } \\
\text { There is a red line between citizens and national } \\
\text { authorities who are good at talking but do nothing[Dis]. } \\
\text { For every project, the politician asks, "How much will I } \\
\text { get out of this" instead of "How } \\
\text { will this be of benefit to society"[Dis]. }\end{array}$} \\
\hline $\begin{array}{l}\text { Facial expression/ } \\
\text { body language }\end{array}$ & $\begin{array}{l}\text { No facial expressions or body } \\
\text { language }\end{array}$ & \\
\hline $\begin{array}{l}\text { Dominant } \\
\text { stakeholders }\end{array}$ & 3 instances (B2 C1,C3) & \\
\hline $\begin{array}{l}\text { Stakeholder } \\
\text { interaction } \\
\text { (groups, } \\
\text { communication) }\end{array}$ & $\begin{array}{l}\text { Central stick figures }(\mathrm{B} 2) \text { but no } \\
\text { interaction with any core theme. } \\
\text { Two stakeholders interacting over } \\
\text { money related matters }(\mathrm{C} 1)\end{array}$ & \\
\hline $\begin{array}{l}\text { Background } \\
\text { Space }\end{array}$ & Top left of picture is blank & \\
\hline Dominant icons & $\begin{array}{l}\text { Central stakeholders ( B2), Issues } \\
\text { regarding waste truck and waste } \\
\text { on mountain (A2),digger cutting } \\
\text { into land to build housing (C2), } \\
\text { relaxed Figure on beach (C3), } \\
\text { Co2 emission from vehicle (B3) }\end{array}$ & \\
\hline $\begin{array}{l}\text { Interesting } \\
\text { metaphor }\end{array}$ & $\begin{array}{l}\text { Unknown communication }(\mathrm{C} 1) \text {, } \\
\text { relaxed figure on beach }(\mathrm{C} 3)\end{array}$ & \\
\hline Isolation & Unknown communication $(\mathrm{C} 1)$ & \\
\hline Speech & 6 instances $(\mathrm{C} 1, \mathrm{C} 2, \mathrm{~B} 2, \mathrm{~A} 2, \mathrm{~A} 3, \mathrm{~B} 3)$ & \\
\hline $\begin{array}{l}\text { Orientation/readi } \\
\text { ng style }\end{array}$ & $\begin{array}{l}\text { No rotation required. Story seems } \\
\text { to be somewhat separated in the } \\
\text { icons at top and bottom right. } \\
\text { Little indication of readable } \\
\text { direction }\end{array}$ & \\
\hline $\begin{array}{l}\text { Specific Icons: } \\
\text { Weather }\end{array}$ & Sun shining $(\mathrm{C} 3)$ & \\
\hline $\begin{array}{l}\text { Specific Icons: } \\
\text { smoking } \\
\text { cigarette/cigar }\end{array}$ & 1 insta & \\
\hline $\begin{array}{l}\text { Specific Icons: } \\
\text { money }\end{array}$ & 1 instance $(\mathrm{C} 2)$ & \\
\hline $\begin{array}{l}\text { Specific Icons: } \\
{ }^{*} \text { psychopathic }\end{array}$ & $\begin{array}{l}\text { Possible skull and crossbones and } \\
\text { coffins but this needs further } \\
\text { confirmation (A3) }\end{array}$ & \\
\hline $\begin{array}{l}\text { Stakeholder } \\
\text { plenary } \\
\text { reflections }\end{array}$ & \multicolumn{2}{|c|}{$\begin{array}{l}\text { Picture IV stresses that heritage is about culture but also old houses and buildings. It also reflects } \\
\text { the difficulty of creating relationships between people and municipalities, which requires time } \\
\text { and a methodology. However, the team should not assume that diversity in a municipal council } \\
\text { is negative; on the contrary, it can be exciting in working with people. }\end{array}$} \\
\hline $\begin{array}{l}\text { Unique Signatory } \\
\text { of the RP }\end{array}$ & \multicolumn{2}{|c|}{$\begin{array}{l}\text { This basic picture depicts a rather bleak scene of costal sustainability. Emigration is } \\
\text { evident but for many icons it is difficult to determine their positive or negative viewpoint. } \\
\text { There is weak development of themes in the RP. Stakeholder EI brings a much better } \\
\text { understanding of the story showing dominant issues of dishonest politicians, low } \\
\text { employment and corrupt government practice. There is a strong sense of disconnection in } \\
\text { decision making. Plenary reflections stress heritage and the difficulty of creating } \\
\text { relationships with community residents and government bodies especially when there are } \\
\text { negative views of a sector. }\end{array}$} \\
\hline
\end{tabular}

sustainability issues that groups examined, but this might not be the case for others studying different problem situations.

Four issues emerged from the RPs of many of the groups. The first theme (Green shading and 'Con') to emerge from the RPs is understandable given the influence of the military and indeed armed groups in general in the country at that time, and they were perceived to have a lot of power. This probably explains the linked issue of a sense of disconnection in decision 


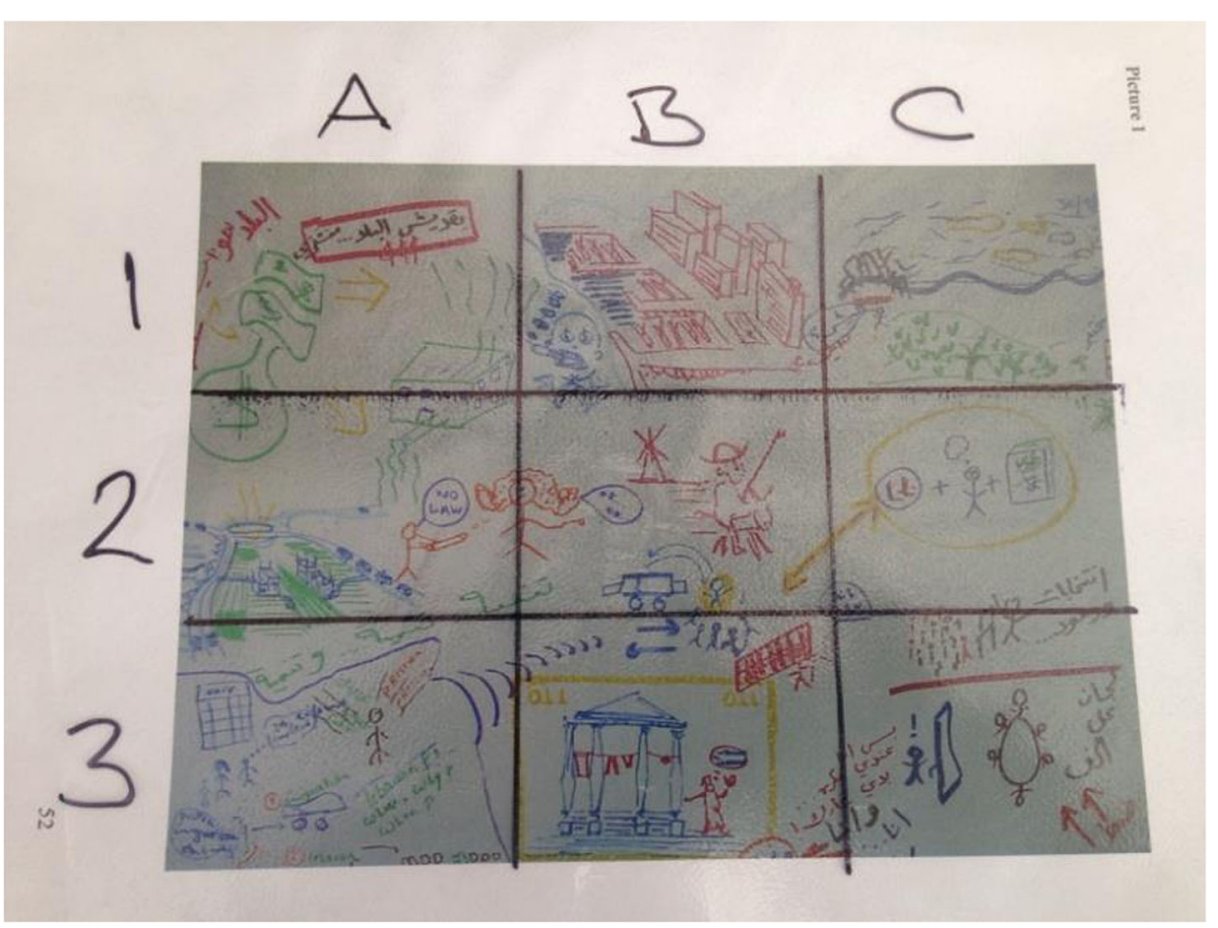

Fig. 5 Example map grid reference for undertaking an Eductive Interpretation of a Rich Picture (example RP in Fig. 1)

making and lack of power amongst those who took part in the workshop (yellow shading and 'Dis'). Military governments are not noted for sharing power. The point about emigration (blue shading and 'Em') is linked to a perceived lack of opportunity within the country and one groups refers specifically to a 'brain drain' and the impacts that this has in terms of achieving sustainability in the coastal zone; a zone subject to many pressures. Finally, and perhaps most telling given that all groups mention it in various forms, is the general sense of poor governance and especially how this is reflected in poor regulation and enforcement of those regulations (Pink shading and 'Reg'). All four of these issues are clearly important and highly prevalent/apparent to those who took part in the workshop.

But while there are common issues between the RPs there are also some interesting differences between the groups. The RP of Group 1, for example, highlights the lack of technical advances in the Lebanon regarding agriculture and fisheries and is the only group to do so. The RP for Group 3 does mention farmers and fishers, but only in the sense that more communication is needed with them to raise awareness of sustainability issues. These differences are significant and would have deserved more investigation after the workshop. It is possible that they may, in part, reflect the specialisms of the group members, but it may also suggest that this lack of technical advances in agriculture and fisheries is not a major issue faced by the country. However, care does need to be taken. Just because an issue may only be raised by one group then it may not necessarily mean that it is unimportant and not worth addressing. The follow-up question here could well be why it is that the issue was only mentioned by the one group. Is it because that group can be thought to have an especial insight by way of its composition? 
Would all of these points emerge if the RPs were repeated now with the same groups? It is certainly possible that some of these themes would still resonate to this day, but it is also likely that others would emerge of the themes would be expressed in different ways.

\section{Discussion}

The nature of this paper has been to set out the value of a new approach to the analysis of RPs using a form of Content analysis called 'Eductive Interpretation'. We argue that this approach is relevant in a wide variety of conventional contexts and that it has emerged in social terms as part of the dynamic which links researcher, context and resulting method. By understanding the deeper meanings emerging from the RP and the social/group issues (often subliminal to the group and/ or obscure and/ or ignored due to a lack of understanding of their importance to group function) implicit in it, social forces in context can be better understood and addressed.

There are off course disadvantages to the EI approach. Firstly, analysis at this level can be rather complex and would take considerable time to complete. We do recognise this might be challenging for those new to CA. Within the EI approach we cannot be too prescriptive in our explanation and decisions will need to be made by the analyst on key themes of group exploration and what the naming and coding conventions will be. We provide a template (Tables 1, 2, 3 and 4) to aid analysis, but our template is geared towards a set of RPs in the sustainability domain and the identified themes might not be suitable for other domains. Secondly, there is wide scope for misinterpretation, oversight of important issues and making links and assumed connections where there are none: apophenia. Apophenia is a great worry for those interpreting the creative works of others. Seeing random associations of incorrect meaning can totally change the whole nature of the intended story or visual intention. Thirdly, there are certainly issues of subjectivity and bias on the part of the coder that arise from EI as they do when applying CA to any qualitative material (Krippendorff 2012).

Perhaps one approach to EI to help combat the issues surrounding apophenia, bias etc. would be to involve a group of coders and combine their individual RP analysis to create a group-agreed analysis. Group rating tools, such as the consensual assessment technique (Baer and McKool 2009), gather a panel of expert judges to rate upon creativity whereas other tools might rate richness and quality using a more individual analysis (Bell and Morse 2013). It is possible, of course, to go further and encourage the workshop participants themselves to undertake the CA - a participatory-based CA - so they can enhance their own learning from a workshop. For the most part, in this paper we have considered the CA of the RPs to be the prerogative of a researcher interested in looking for patterns etc. across individuals or groups. While this is, of course, a perfectly valid use of the CA we set out here, the involvement of participants in the CA may offer new levels of knowledge co-generation (Thorpe et al. 2011). Indeed, such an approach would perhaps be the peak of such co-generation of knowledge within participation, with each group generating its own analysis (via RPs) and participants generating their own CA of the multiple RPs produced by all groups. Identifying and answering these questions may potentially be a powerful catalyst for learning that extends the life of the interaction that they undertook. After all, projects and workshops tend to have a limited lifespan - an event horizon that once crossed has no way back. Participatory CA may help facilitate an ongoing learning that goes beyond that horizon.

In the Lebanon workshop, an EI of the RPs pointed towards four themes that the groups thought were important, and clearly these need to be considered as interventions are introduced 
and discussed. But the EI took place long after the workshop and did not form part of it. The task of the workshop facilitator was to allow the groups to travel their own roads and come up with their own suggestions regarding coastal management, and it has to be stressed that is all the funder wanted. The result was four sets of collective voices with no attempt to go beyond that. Nonetheless, the subsequent EI of the RPs raises all sorts of issues, similarities and differences that certainly provide much food for thought with regard to the coastal zone. Hence, we would argue that the use of EI is a step up; an attempt to go beyond individuals or even groups in a workshop so as to understand why it is that certain issues are dominant while others are not.

\section{Conclusion}

Content analysis via Eductive Interpretation upon Rich Pictures has the potential to bring together a deep visual understanding of a plethora of world views within an existing community system. Social issues can be identified using a platform of participatory workshops to identify concerns and key matters through pictorial metaphor. It is our belief that for some very complicated projects involving many stakeholders a high-level analysis upon a group of RPs drawn under the same conditions and reflecting upon the same issue can reveal more than just similarities and differences. The RP in SSM provides stakeholders with an opportunity to engage with and respond to other and alternative worldviews. If some issues are raised by many groups yet others are raised by just one group, then both should be worthy of further exploration. The EI provides further avenues to explore rather than seeking to close the door. Nevertheless, the authors recognise that there is a danger that the EI will be employed in a simplistic way to seek out issues mentioned most often as a means of focussing effort. Such a decision needs to be taken with care.

Acknowledgements This article would not exist without the opportunity provided to undertake the workshops by Plan Bleu (http://planbleu.org/en) and without the input of many Lebanese citizens. The authors extend their gratitude to all who made this work possible.

Open Access This article is distributed under the terms of the Creative Commons Attribution 4.0 International License (http://creativecommons.org/licenses/by/4.0/), which permits unrestricted use, distribution, and reproduction in any medium, provided you give appropriate credit to the original author(s) and the source, provide a link to the Creative Commons license, and indicate if changes were made.

Publisher's Note Springer Nature remains neutral with regard to jurisdictional claims in published maps and institutional affiliations.

\section{References}

Avison D, Fitzgerald G (2006) Information systems development: methodologies, techniques and tools (4th Editio.). McGraw Hill, Maidenhead

Azar F (2002) Muslims and Christians in Lebanon: common views on political issues. J Peace Res 39(6):735746

Baer J, \& McKool SS (2009) Assessing creativity using the consensual assessment technique. In Handbook of research on assessment technologies, methods, and applications in higher education (pp. 65-77). IGI Global

Ballard E (2007) Improving the discharge planning process: a systems study. J Res Nurs 12(6):687-688

Bell S, Morse S (2012) How people use rich pictures to help them think and act. Syst Pract Action Res 26(4): 331-348 Available at: http://link.springer.com/10.1007/s11213-012-9236-x. Accessed 27 Nov 2014 
Bell S, Morse S (2013) Rich pictures: a means to explore the "sustainable mind". Sustain Dev 21(1):30-47

Bell S, Berg T, Morse S (2016) Rich pictures: encouraging resilient communities Earthscan. Taylor and Francis, London

Berg T (2013) Understanding iconography: a method to allow rich picture interpretation to improve. Heriot Watt University, Edinburgh

Boedhihartono A (2012) Visualizing sustainable landscapes: understanding and negotiating conservation and development trade-offs using visual techniques. International Union for Conservation of Nature, Gland Available at: www.iucn.org/publications

Bronte-Stewart M (1999) Regarding rich pictures as tools for communication in information systems development. Comput Inf Syst 6(2):85-104

Callo Y, \& Packham R (1997) Soft systems methodology: it's potential for emancipatory development. In Australia and New Zealand systems society conference. Institute of Continuing and TESOL Education, the University of Queensland, Brisbane, Australia

Campbell-Hunt DM (2008) Ecotourism and sustainability in community-driven ecological restoration: Case studies from New Zealand, 115, p.231. Available at: http://libezproxy.open.ac.uk/login?url=http://www. scopus.com/inward/record.url?partnerID=yv4JPVwI\&eid=2-s2.0-58849090028\&md5=b8b67e25efd697 $\mathrm{a} 052 \mathrm{a} 60054 \mathrm{fb} 6 \mathrm{f} 05 \mathrm{~b} 5$

Carrizosa A (2002) Rich pictures, metaphors and stories as mechanisms to improve collective actions. Synergy Matters, pp 43-48. Available at: http://libezproxy.open.ac.uk/login?url=http://www.springerlink. com/content/gh20u753nu2p2755/

Checkland PB (1981) Systems thinking, Systems practice. Wiley, Chichester

Checkland P, Poulter J (2006) Learning for action: a short definitive account of soft systems methodology, and its use practitioners, Teachers and Students. Wiley, Chichester

Fougner M, Habib L (2008) If I had a rich picture: insights into the use of "soft" methodological tools to support the development of interprofessional education. J Interprof Care 22(5):488

Haynes M (1989) A participative application of soft systems methodology: an action research project concerned with formulating an outline design for a learning Centre in ICI chemicals and polymers. University of Lancaster

Krippendorff K (2012) Content analysis: an introduction to its methodology, Third edn. Sage, London

Langsdale SM, Beall A, Carmichael J, Cohen SJ, Forster CB, Neale T (2009) Exploring the implications of climate change on water resources through participatory modelling: case study of the Okanagan Basin, British Columbia. J Water Resour Plan Manag 135(5):373-381

Mazijoglou M, Scrivener S (1998) The rich picture of design activity. Autom Constr 7(2-3):157

Mingers J (2001) An idea ahead of its time: the histrory and development of soft systems methodology. Syst Pract Action Res 13(6):733-756

Pfeiffer C, Glaser S, Vencatesan J, Schliermann-Kraus E, Drescher A, Glaser R (2008) Facilitating participatory multilevel decision-making by using interactive mental maps. Geospat Health 3(1):103-112

PlanBleu \& Bell S (2002a) The systemic and prospective sustainability analysis: Wokshop 1, Sophia Antipolis

PlanBleu \& Bell S (2002b) The systemic and prospective sustainability analysis: workshop 2, Sophia Antipolis

PlanBleu \& Bell S (2003a) The systemic and prospective sustainability analysis: workshop 4, Sophia Antipolis

PlanBleu \& Bell S (2003b) The systemic and prospective Sustainabilty analysis: workshop 3, Sophia Anitpolis

Probert S (1998) A critical analysis of soft systems methodology and its (theoretical and practical) relationship with Phenomenaology. Systemist 21:187-207

Proctor T (1995) Computer produced mind-maps, rich pictures and charts as aids to creativity. Creat Innov Manag 4(4):242-250

Stamper R, \& Kolkman M (1990) Soft systems techniques with a sharp(er) edge: unit systems and systems properties. In presented at the international conference on systems management 90 . Hong Kong

Sutrisna M, Barrett P (2007) Applying rich picture diagrams to model case studies of construction projects. Eng Constr Archit Manag 14(2):164-179

Thorpe R, Eden C, Bessant J, \& Ellwood P (2011) Rigour, Relevance and Reward: Introducing the Knowledge Translation Value-chain. Br J Manag 22:420-431

Winter M, Checkland P (2003) Soft systems: a fresh perspective for project management. Civ Eng 156:187-192 